\title{
State formation in early medieval Castile: craft production and social complexity
}

\author{
Francesca Grassi ${ }^{1, *}$, Juan Antonio Quirós Castillo ${ }^{1}$, Ainhoa Alonso \\ Olazabal $^{2}$, Luis Angel Ortega ${ }^{2} \&$ Cristina Fornacelli ${ }^{3}$
}

The EARMEDCASTILE project, based at the University of the Basque Country, has received funding from the European Union's Horizon 2020 Research and Innovation Programme, Marie Sklodowska-Curie Action (grant agreement 656540); http://earmedcastile.blogspot.com).

The main goal of the project is to study the formation and transformation of the local and central political institutions of northern Iberia during the Early Middle Ages, analysing craft production, exchange systems and consumption patterns as markers of social and political complexity. In order to achieve these aims, the project adopts an interdisciplinary approach, with an emphasis on archaeological science techniques, to examine the lifestyles of social elites and the means by which they extracted revenues, as well as other archaeological indicators of power and influence (for a preliminary report, see Grassi 2016).

The main innovations of the project are:

- A social theory approach to the emergence and collapse of local and central political institutions.

- An archaeological perspective on political complexity in the hitherto unexplored area of northern Iberia (Quirós Castillo 2016).

- An interdisciplinary evaluation of the significance of different archaeological markers for the analysis of early medieval states.

- A territorial definition of early medieval states based on commercial exchange.

- A comparison of early medieval northern Iberia with other European contexts.

In recent years, large-scale research and rescue archaeological projects have yielded considerable information regarding early medieval sites and assemblages. Based on this new evidence, we will analyse the ceramic material from 15 sites dated to the early medieval period (sixth to tenth centuries AD) (Figure 1).

1 Faculty of Arts, University of the Basque Country, Francisco Tomas y Valiente Street, 01006 Vitoria-Gasteiz, Spain

2 Faculty of Science and Technology, University of the Basque Country, Barrio Sarriena, 48940 Leioa, Bizkaia, Spain

3 Department of Physical Sciences, Earth and Environment, University of Siena, Laterina Street 8, 53100 Siena, Italy

* Author for correspondence (Email: fragrass20@gmail.com)

(C) Antiquity Publications Ltd, 2017 ANTIQUITY 91 358, e6 (2017): 1-5 


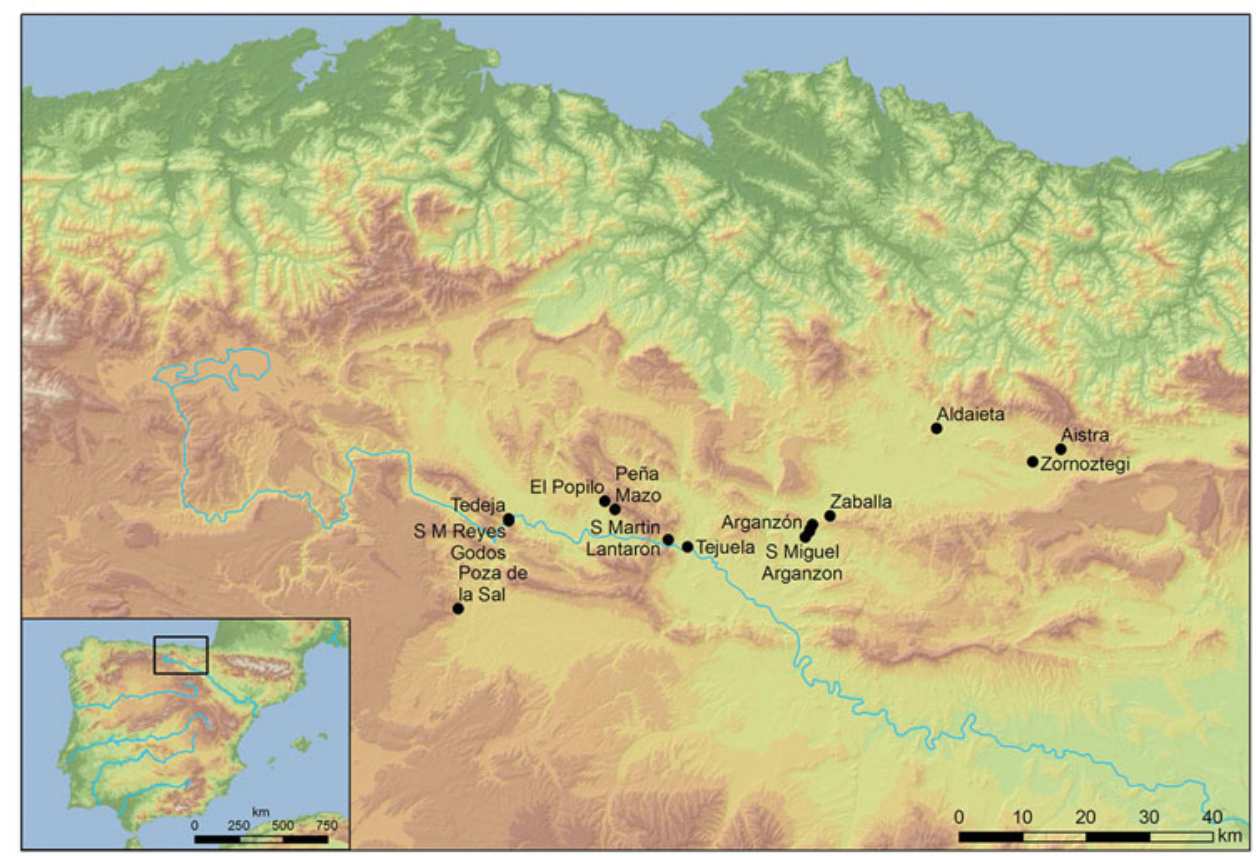

Figure 1. Location of the sites included in the EARMEDCASTILE project.

The first phase of the project focuses on cataloguing material and sampling ceramics, prior to archaeometric analysis. We are working on a collection of almost 15000 fragments, totalling $118 \mathrm{~kg}$ and representing 1314 different vessels (Figure 2). The 15 selected sites are located in three different geographic areas in the north of Spain: the upper Ebro, the Miranda of Ebro basin and the Alava Plain. Nearly all the sites are long-term settlements, the earliest occupation phases of which date back to the protohistoric or Roman periods. All were continuously occupied throughout the Middle Ages. The study region includes the historical County of Castile, which existed between AD 816 and 931, and which depended on the Kingdom of Asturias (Estepa Diez 2009) (Figures 3-4).

The project involves a large-scale archaeometric study of early medieval ceramics in Castile, with the aim of identifying the key production centres (Grassi \& Quirós Castillo in press). Special attention is paid to categories such as red-painted pottery (Figure 5), which travelled widely across the northern Iberian Peninsula (upper Ebro Valley, western Pyrenees), as indicators of inter-regional exchange (Fornacelli \& Grassi in press).

The scientific examination of the samples includes petrographic, mineralogical and textural analysis of the fabrics, as well as inclusions, using optical microscopy. Chemical analysis (ICP-MS and ICP-OES) is also undertaken in order to collect further information about the properties and the provenance of the raw materials. All data are stored in the online GIS platform, Medieval Archaeology of Northern Iberia (ARMENOP; (C) Antiquity Publications Ltd, 2017 


\begin{tabular}{|c|c|c|}
\hline & Site (District) & Site type \\
\hline \multirow{6}{*}{$\begin{array}{l}\text { Miranda de Ebro } \\
\text { basin }\end{array}$} & 1 Arganzón, San Miguel (Burgos) & medieval village \\
\hline & 2 Arganzón, Castillo (Burgos) & castle \\
\hline & 3 La Erilla (Burgos) & medieval village \\
\hline & 4 Arganzón, El Convento (Burgos) & medieval village \\
\hline & 5 San Martín de Lantaron (Alava) & medieval village \\
\hline & 6 Tejuela, Villanueva de Soportilla (Burgos) & medieval village with cemetery \\
\hline \multirow[t]{4}{*}{ Alava Plain } & 7 Zaballa (Alava) & medieval village \\
\hline & 8 Zornoztegi (Alava) & medieval village \\
\hline & 9 Aistra (Alava) & medieval village \\
\hline & 10Aldaieta (Alava) & medieval cemetery \\
\hline \multirow[t]{5}{*}{ Upper Ebro } & $\begin{array}{l}11 \text { La Peña Mazo, Pajares, Valle de Tobalina } \\
\text { (Burgos) }\end{array}$ & medieval village \\
\hline & 12EL Pópilo, Herrán, Valle de Tobalina (Burgos) & medieval village \\
\hline & 13Poza de la Sal, El Castillo (Burgos) & castle and hamlet \\
\hline & 14Tedeja, Trespaderne (Burgos) & medieval castle \\
\hline & $\begin{array}{l}\text { 15Santa María de los Reyes Godos -Tedeja } \\
\text { (Burgos) }\end{array}$ & $\begin{array}{l}\text { early medieval church near Tedeja } \\
\text { castle }\end{array}$ \\
\hline
\end{tabular}

Figure 2. Characterisation of the study sites.
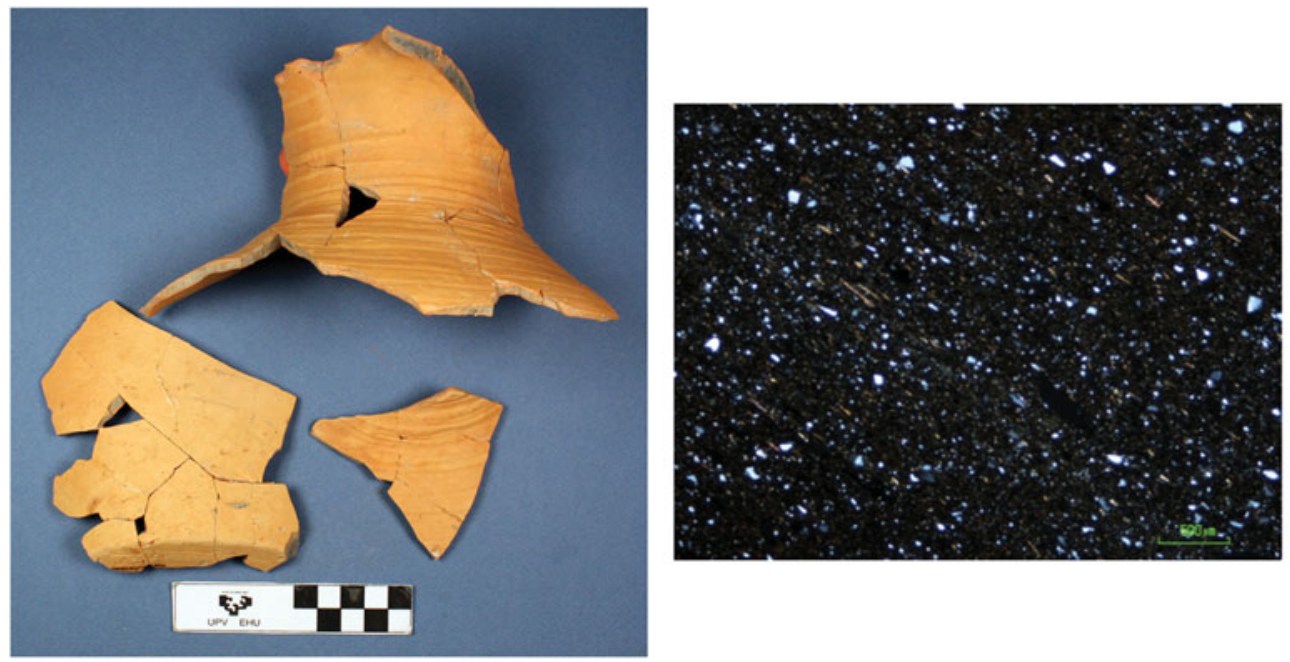

Figure 3. Example of inter-regional circulation: medieval jug from Zaballa (eighth to ninth centuries AD), and microphotograph showing the fabric.

http://worldmap.harvard.edu/maps/ARMENOP), created by the Research Group on Cultural Heritage and Landscapes (http://www.ehu.es/en/web/culturalheritage/home).

EARMEDCASTILE's goal of linking the analysis of local-scale events with wider political institutions, and their ongoing formation and collapse, poses several challenges (Escalona Monge 2011). Taking into account that this region was characterised by an absence of urban centres, by geographic fragmentation caused by natural barriers, and by the lack 


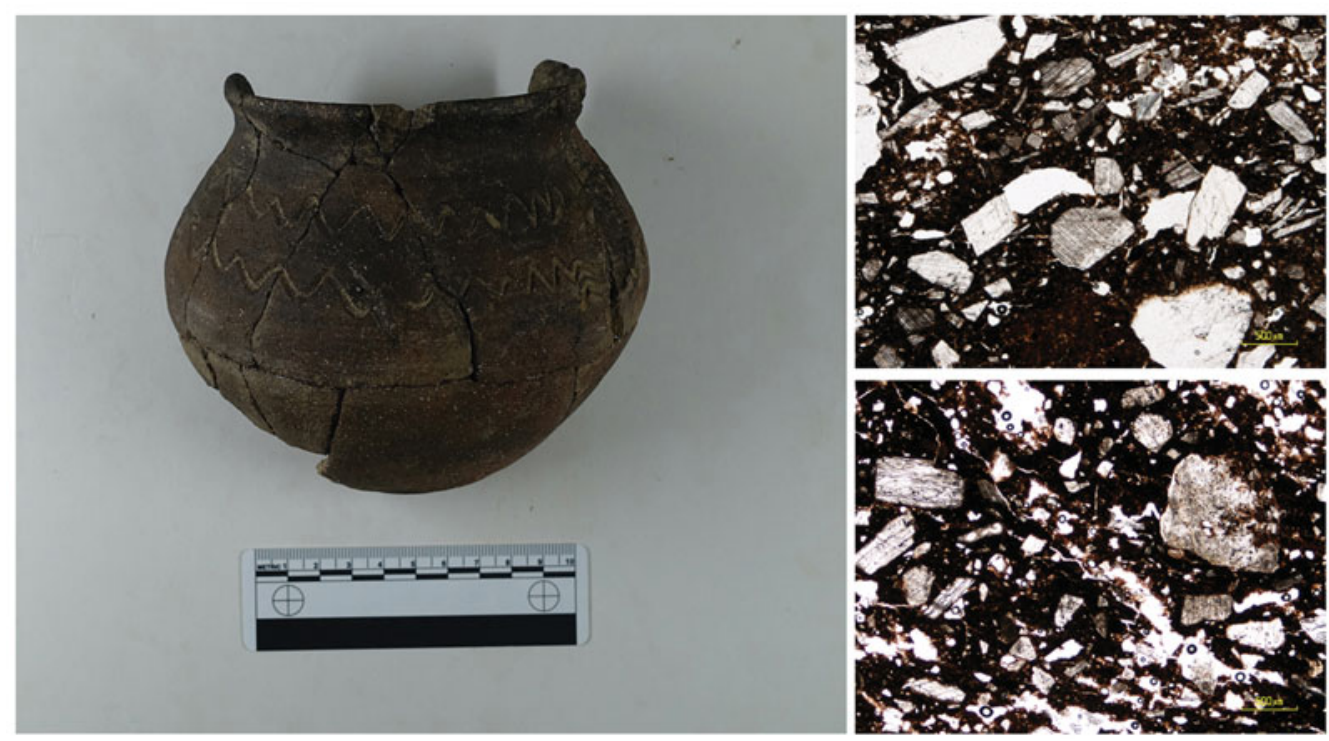

Figure 4. Locally produced pottery: medieval pot from Aldaieta (sixth to seventh centuries AD), and microphotographs showing the fabric (parallel nicols, magnification $2.5 \times$ ).
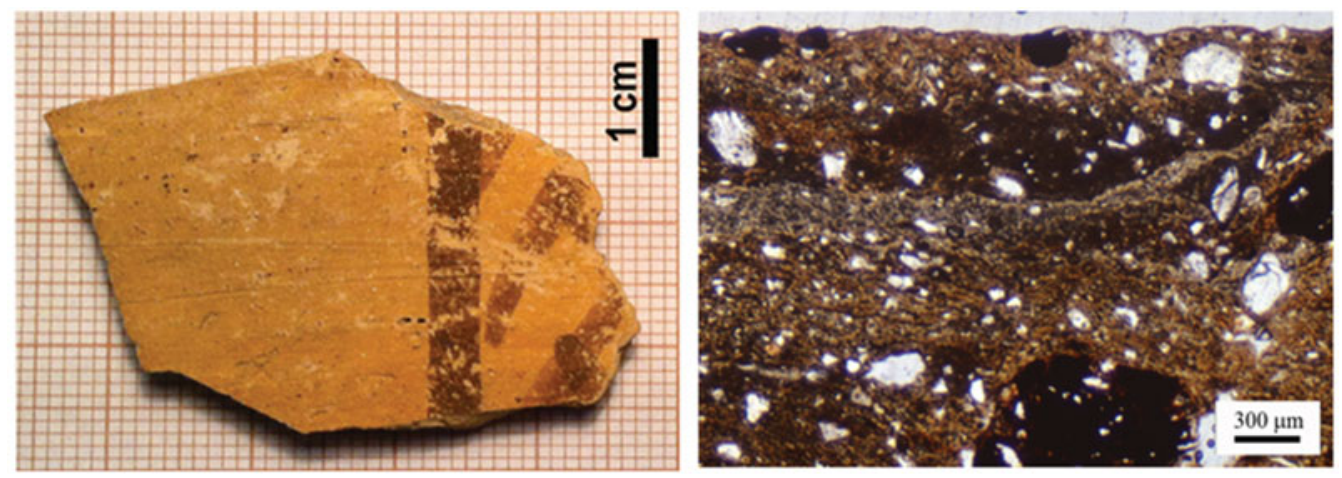

Figure 5. Ebro Valley-produced pottery: red-painted from Poza de la Sal (eighth to ninth centuries AD), and microphotograph showing the fabric (parallel nicols, magnification $2.5 \times$ ).

of inter-regional exchange hubs such as emporia, it is, in general, plausible to suggest the existence of direct marketing mechanisms, of varied levels of complexity. On top of this fragmented socio-political system, the short duration of centralised polities also influenced the production, consumption and distribution of pottery. For example, existing potteryproduction and -circulation systems survived into the Visigothic period, starting in the sixth century, but were complemented by new productions with their own distributions, responding primarily to social differentiation within village settlements. Later, from the eighth century onwards, the internal transformation of these villages coincides with the emergence of new productions and with a large expansion in circulation, which extends into other regions. This trend seems to continue with the formation of the County of (C) Antiquity Publications Ltd, 2017 
Castile in the tenth century, and shows a progressive intensification and standardisation of local distribution, while inter-regional exchange of ceramics is increasingly indicative of the emergence of new local powers rooted in the settlements of the study area.

\section{References}

Escalona Monge, J. 2011. The Early Middle Ages: a scale-based approach, in J. Escalona Monge \& A. Reynolds (ed.) Scale and scale change in the Early Middle Ages. Exploring landscape, local society and the world beyond: 9-30. Turnhout: Brepols.

Estepa Diez, C. 2009. La Castilla primitiva (750-931): condes, territorios y villas. Territorio, Sociedad y Poder 2: 261-78.

Fornacelli, C. \& F. Grassi. In press. New archaeometrical data on red-painted pottery: case study of northern Iberia, in F. Grassi \& J.A. Quirós Castillo (ed.) Arqueometría de los materiales cerámicos en el norte de la Península Ibérica: métodos $y$ estrategias para el futuro. Bilbao: UPV/EHU.
Grassi, F. 2016. Production, consumption and political complexity: early medieval pottery in Castile, in J.A. Quirós Castillo (ed.) Social complexity in early medieval rural communities. The north-western Iberia archaeological record: 91-113. Oxford: Archaeopress.

Grassi, F. \& J.A. Quirós Castillo (ed.). In press. Arqueometría de los materiales cerámicos en el norte de la Península Ibérica: métodos y estrategias para el futuro. Bilbao: UPV/EHU.

Quirós Castillo, J.A. (ed.). 2016. Social complexity in early medieval rural communities. The north-western Iberia archaeological record. Oxford: Archaeopress. 